\title{
A Discursive Approach to Aporia in The Turn of the Screw
}

\author{
YE La-mei \\ Shenzhen University, Shenzhen, China
}

\begin{abstract}
Henry James's The Turn of the Screw (1898) is a fascinating thriller that bewilders readers and critics alike for more than 100 years since its publication. Based upon the analytic frame of Bakhtin's critical vision on conceptual horizons, and the double-voiced active discourse, this paper seeks to locate the recurrence of aporia through a tracing of the varied speakers and listeners in the text, and the varied discourses viewed from the stance of an implied author, for which all contribute to the cloudy effect of the novel. The author argues that conceptual horizons and double-voiced active discourse both possess the power of bringing about ambiguity in textual understanding. This study intends to broaden critics' horizon and diversify the appreciation of this work.
\end{abstract}

Keywords: conceptual horizons, double-voiced active discourse, aporia, The Turn of the Screw

\section{Introduction}

While first reading Henry James's The Turn of the Screw (1898), many readers tend to be totally at loss as to whether the ghosts in the story are real or imaginary. The story is told 20 years later from a manuscript written by the unnamed governess before her death. It is about the governess's personal experience in the community of Bly, where she, the youngest daughter of a pastor from the countryside, was employed by a rich bachelor as a governess to his nephew - ten-year-old Miles and his niece-eight-year-old Flora. During her stay in Bly, uncanny things occurred: she frequently encountered the apparitions of ghosts. The governess suspected that there was an erotic relationship between the two children and the ghosts (which she considered to be the ghosts of the former valet Mr. Quint and the former governess Miss Jessel). Her curiosity and determination to ply truth out of the children only led to intense hatred on the part of Flora and the tragic death of the boy.

Since the publication of the story, there has been much controversy over the existence or non-existence of the ghosts. The author's concern in the present paper, however, is not to determine the presence or absence of ghosts, but to explore the overwhelming sense of perplexity created by the story. In undertaking such an exploration, the author does not mean that the kind of perplexing effect is prevalent everywhere in the text. A general survey of existing reviews on James's works shows that critics generally agree that perplexity is indeed a dominant feature affecting most of James's works. Among his works, The Turn of the Screw (1898), hereafter The Turn (1898) is the one that draws most critical attention to the effect of ambiguity and confusion.

Henry James (1843-1916) is a productive and experimental writer, whose work has been widely reviewed and analyzed both during his lifetime and after. As a conscientious writer and critic in his own right, James never refrained from talking about his own productions either in the prefaces to his works or in his correspondence with friends. His critical prefaces were collected in The Art of the Novel (1934). His critical

YE La-mei, MA, Associate Professor, Foreign Language Institute, Shenzhen University. 
essays on other writers' works were collected in Literary Reviews and Essays on American, English and French Literature (1958). In the study, the author will preclude James's critical comments on The Turn (1898), and only engage him as an implied author.

Among his oeuvre, The Turn (1898) is regarded as a masterpiece of ghost tale. In spite of the tremendous anxiety of the influence posed by James's American predecessors Nathaniel Hawthorn (Birthmark, 1843), Edgar Allen Poe (The Purloined Letter, 1844), and the prevalent fashion of telling ghost tales in England during his lifetime, James's novel has proven its worth, sustained its captivating power over readers and attracted critical attentions for more than 100 years after its publication.

There have been many reviews of this novel. A general survey of critical readings between 1898 and 1934 manifests a critical preoccupation with the presence or absence of the ghosts in the novel. And those critical reviews might be classified into apparitionists and nonappartionists. The apparitionists believe that ghosts did visit the governess and the children concealed their malign relations with the ghost; the nonapparitionists, on the other hand, maintain that the ghosts are illusions of the insane governess, who is responsible for the dispossession of Miles' life, in spite of her affection towards the boy.

With the advent of Edmund Wilson's work “The Ambiguity of Henry James” in the year 1934, this ghost tale started to enjoy a different voice: "[A]lmost everything from beginning to end can be read equally in either of two senses" (as cited in Cranfill \& Clark, 1965, p. 6). Wilson made initial steps pointing out the indeterminacy in reading The Turn (1898). Apart from this, he regards the governess as "a victim of neurotic sexual repression”, and “one of James’s frustrated spinsters” (as cited in Cranfill \& Clark, 1965, p. 6). However, Wilson still sided with the camp of nonapparitionist.

In his The Ambiguity of Henry James (1971), Samuels explored the puzzling effect caused by the reading of this ghost tale. He adopted a semantic approach to this topic, and came up with an exhaustive list of textual evidence to support his argument that the novel is confusing. He rejected Wilson's nonapparitionist view, and concluded "that James was as unable to castigate evil as he was to affirm virtue" (Samuels, 1971, p. 22). He ranked The Turn of Screw (1898) among the least successful of Henry James's novels. To him, perplexity is a hallmark of failure to write with clarity.

In The Insecure World of Henry James's Fiction: Intensity and Ambiguity (1982), Norrman joined the attempts to explain the ambiguities in James's novels. He based his argument on the belief that "the style reflects the man” (Norrman, 1982, p. 1). Motivated by such a belief, he approached the issue from the rhetorical angle, and underpinned several rhetorical devices—chiasmus, end-linking, oxymoron and antithesis—as the dominant features of James's novel, which contribute to the uncertainty of the identities of Jamesian characters. With these figurative devices, Norrman (1982) argued, James danced a strange dance: “[O]ne step forward, two steps backward" (p. 1)

With regard to previous scholarship on the ambiguity of James's The Turn (1898), the paper does not pretend to deal with a novel topic. These previous researches confirm the existence of an unmistakable effect of ambiguity in the reading of this novel. The author's concern in this paper is to examine how these moments of ambiguity have been produced.

This paper tackles the issue with Bakhtin's theory of dialogism. The Turn is written after James's humiliating failure in play writing in late 1895 (James, 1985, p. 8). This novel abounds in instantaneous dialogues, which might be regarded as a traceable trait of James play writing. Bakhtin's notion of "conceptual horizon" is of great helps in explaining the conflicts between the speaker and listener within a dialogue. The 
presence of such conflicts necessitates a choice in interpretation. To make this difficult choice, the readers actually are pressed to the tension of indeterminacy.

Bakhtin's theory of double-voiced discourse conflates the author's discourse and the protagonists' discourse within one presented textual discourse. He argued that within one discourse, both the author's and the protagonist's semantic intentions appear. Hence in reading one textual discourse we actually listen to two voices, our interpretation of the text is constrained by the tension of these two voices. This is another clue to locate the aporia in The Turn.

\section{A Discursive Model for Textual Analysis}

This paper seeks to locate and explain the occurrence of aporia in the light of Bakhtin's theory of the dialogic nature of language and the double-voiced discourse of the novel.

According to Bakhtin, behind each individual speaking voice there is a "conceptual horizon", a term used by Bakhtin to describe the various social languages the speaker or the listener inhabits/uses. This 'conceptual horizon' is characteristic of the individual speaker's possession of language, and may or may not correspond to/agree with the "conceptual horizon" of his/her audience. When the two "conceptual horizon" conflict, meaning as produced in the speaker's "conceptual horizon" is likely to be refracted and become different in the audience's “conceptual horizon”. This theory is helpful in locating aporia because when the speaker's intention misfires, when s/he is misunderstood by the audience, when two people each speak in their own language with their intentions not really relayed to their audience, aporia actually occurs.

In advancing the notion of "conceptual horizon”, Bakhtin is primarily concerned with listener and speaker within a dialogue, but this notion also applies to a written discourse. Bakhtin's observation of the centripetal and centrifugal forces within every levels of language has anticipated reader response theories in literary studies. The postmodern turn of reader response theory is in fact an extension of Bakhtin's concern with listeners inside a text to the concern of the audience or readers outside a text.

Bakhtin's theory of double-voiced discourse of a novel also proves helpful in explaining aporia. In his essay "Discourse in the Novel", Bakhtin proposes that a novel, as a spoken discourse, is not a composite of impersonal and prevocal signifiers; rather, it is charged with ideology ${ }^{7}$ (1981, p. 333). In Problems of Dostoevsky's Poetics, Bakhtin posits the author's discourse in relation to the protagonist's discourse, and argues that there are two semantic intentions within one textual discourse: one is the author's intention; the other is the protagonist's intention. The author's discourse is hidden and interacts with the protagonist's discourse.

Bakhtin identifies three types of double-voiced discourse: the unidirectional, the varidirectional and the active discourse (1984, p. 193). The unidirectional discourse is the one that the author adopts to express his own aspirations. The varidirectional discourse is the author's stylization of a certain discourse for parody or other purposes. In the active double-voiced discourse, the protagonist's discourse assumes an authority over the author's discourse. But the author's discourse interacts with the protagonist's discourse and subverts it in a hidden way through what Bakhtin calls the "hidden polemic". ${ }^{\circ}$

\footnotetext{
7 "A particular language in a novel is always a particular way of viewing the world, one that strives for a social significance." (Dialogical Imagination 333) This striving “for a social significance” is termed "ideology” by Bakhtin.

8 "In a hidden polemic the author's discourse is directed towards its own referential object, as in any other discourse, but at the same time every statement about the object is constructed in such a way that, apart from its referential meaning, a polemical blow
} 
Bakhtin's theory of double-voiced discourse does not make a distinction between the author outside the text and the implied author of the text. With the advent of the poststructuralist Roland Barthes's The Death of the Author (1968), "author" has become a problematic term in the critical world. According to my observation of "author" as used by Bakhtin, his conception of author is close to both the external narrator, as occurred in the works of narratologists like Mieke Bal and Gennete, and the implied author, ${ }^{9}$ as mentioned by Wayne C. Booth in his The Rhetoric of Fiction (1987). My critical engagement with the concept of "author" precludes the author outside the text, and regards the author mentioned here as the implied author within the text. I don't adopt the term external narrator because that term is more applicable to stories. The term implied author is applicable to more genres of literary writings than just stories.

Bakhtin's dialogism has brought about a fundamental change to the philosophy of language: language is no longer considered as transparent representation of things. To Bakhtin, every word and every speech is loaded with ideology. Language competes with each other at all levels: a single semantic unit, a dialogue, and a piece of discourse. However, his double-voiced discourse does not include the reader's voice in his study. In reading a text, the reader actually starts a dialogue with the text. The text may speak through the reader, which makes the author's voice and the protagonist's voice heard. The reader also has a distinct voice of his/her own. Without a reader's participation in reading the text, the voices within the text are muted.

According to Bakhtin's classifications of the double-voiced discourse of the novel, the double-voiced discourse of The Turn is of an active type. In the embedded story of The Turn, the governess assumes an authoritative position in relating her story, however, with the "hidden polemic" constructed by James, her authority in telling the story is subjugated to a hard blow.

The following is a detailed analysis of James's text based upon Bakhtin's theory of "conceptual horizons" and double-voiced active discourse.

\section{“Conceptual Horizon” of Listeners and Speakers}

In advancing his notion of "conceptual horizon", Bakhtin is concerned with the speaker and the listener within a dialogue. What he fails to take into account is the reader's participation in the dialogue within the text. The reader, of course, brings his/her own conceptual horizon to bear on the dialogue.

In "Discourse in the Novel" (1987), Bakhtin argues that a speaker or a listener carries with him/her a baggage of social languages. A speaker uses his/her possession of languages to express his/her intention; however, when the speech enters into the listener's sphere of understanding, that is, the listener's possession of languages or, in Bakhtin's term, the listener's domain of discourse, the meaning of the same speech will be decided not by the speaker but by the listener. The difference between the speaker and the listener's possession of languages actually forms a horizontal gap.

On this ground of Bakhtin's theory, it can be inferred that dialogues actually take place at the interface of

is struck at the other's discourse on the same theme, at the other's statement about the same object." (Problems of Dostoevsky's Poetics, p. 195)

${ }^{9}$ The implied author is a concept of literary criticism developed in the twentieth century. It is distinct from the author and the narrator. The distinction from the author lies in that the implied author consists solely of what can be deduced from the work. The implications of the work may paint a rather different picture of the author that might be deduced from his real life. The Free Encyclopedia, retrieved December 11, 2006 from http://en.wikipedia.org/wiki/Implied_author. 
the speaker's and the listener's “conceptual horizons”. In Bakhtin's words, “discourse lives on the boundary between its own context and another, alien, context” (1981, p. 273). More specifically, the speaker's "conceptual horizon" is a context for starting the dialogue, while the listener's "conceptual horizon" serves as an alien context for the reception of the speaker's speech. Owing to the difference in "conceptual horizons", meanings of certain words can vary significantly in distinctive speech contexts. For instance, in The Turn, the governess's speech context is quite different from that of Mrs. Grose's, and more so from those of Miles's and Flora's. Since the conceptual horizon refracts the meaning of an utterance in all possible directions, it is the listener who eventually decides how certain words will be received.

Bakhtin points out that "the word in language is half someone else's" (1981, p. 294). If the speaker produces an utterance with his/her intention in it, s/he needs to undergo a dialogic process to make his meaning of the word accepted by the listener. If the listener interprets his utterance differently from his/her original intention, then a split between the speaker's intention and the actual performance of the speech act occurs in the dialogue. Regarding that fact, Bakhtin concludes that "Expropriating it (the utterance), forcing it (the utterance) to submit to one's own intentions and accents, is a difficult and complicated process" (1981, p. 294). Bakhtin calls this dialogic process an "ideological becoming" process, (Bakhtin, 1981, p. 342) in which any individual who attempts to forge an authentic voice, or to impose one's own idea in the language s/he uses, has to face various obstacles incurred by this dialogic nature of language. ${ }^{10}$

With reference to this observation, Bakhtin claims that the essential quality of language is dialogic. A further exploration in The Turn will show how the governess encounters great difficulties in her efforts to put across her ideas and opinions to the co-characters. The difficulties of this "ideological becoming" process also increase the undecidability in reading this story. As a reader, my work of locating this indeterminacy completes the circulation link among author, text and readers. The following is an example of aporia resulted from the difference in conceptual horizons.

Examples from The Turn will show that the meaning of an utterance the governess wants to put across is received differently in Mrs. Grose's discourse and the children's discourse. The semantic and expressive intention of the governess in producing an utterance is quite different from the contexts of understanding and speaking that utterance by Mrs. Grose, Miles and Flora respectively.

The following dialogue occurs between the governess and Mrs. Grose. The governess is inquiring about the manners of behavior of the former valet Mr. Quint, especially when the latter spent his time with Miles, Flora and Miss Jessel.

[The governess:] "The time they (Miles and Flora) were with him, and his name, his presence, his history, in any way.” ... [Mrs. Grose answers:] “Quint was much too free.” This gave me, straight from my vision of his face-SUCH a face!—a sudden sickness of disgust. “Too free with MY boy?” “Too free with everyone!” (James, 1960, pp. 29-30) ${ }^{11}$

Mrs. Grose uses the word "free" in the negative sense. In the dictionary entry, the word "free" in the negative sense could mean "take undue liberties" or "overfamiliar". Upon hearing this word, the governess feels "a sudden sickness of disgust” and immediately associates the word "free” with "MY boy” Miles. To her, "free" indicates intimacy. The capitalized "MY" shows that the governess already regards Miles as her

\footnotetext{
10 Honecutt, Lee. "Bakhtin and His World". Retrieved June, 2006 from http://www.public.iastate.edu/ honeyl/bakhtin/chap2b.html.

${ }_{11}$ All quotations from the text of The Turn of the Screw come from A Casebook on Henry James's The Turn of the Screw. The text is the first American appearance in book form.
} 
possession and cannot bear to hear his being ever possessed by someone else.

With Mrs. Grose, however, "Too free with everyone" seems to bear an intention to dissolve the enragement that has been aroused in the governess upon her seeing the "free" relationship between Miles and Mr. Quint. It is quite apparent that the word "free” used in Mrs. Grose's domain of discourse is less strong than its reception in the governess's domain of discourse, because Mrs. Grose is simply uneasy when she talks about Mr. Quint being "free with everyone”, while the governess is disgusted at the thought that Mr. Quint is "free” with little Miles. Probably the "free" relationship as conceived by the governess is not as simple and pure as indicated by the word "free" when used by Mrs. Grose. Confronted with such an ambiguous use of "free", readers might wonder which layer of meaning of the word "free" is truer in revealing the case. Consequently the relationship between Mr. Quint and Miles becomes ambiguous and unresolved, leaving the reading full of doubts and suspense.

The following dialogue occurs between the governess and little Flora at a time when the governess discovers that Flora, instead of staying in the bed during the night, is standing before the window and looking out. When questioned by the governess regarding her getting up at night, Flora explains that she guesses that someone might be walking in the grounds. When the governess asks Flora if she has seen someone, Flora answers with a definite "no". The following quotation shows how hard the governess tries to establish connection between Flora's behavior and what she fancies to be the relationship between Flora and Miss Jessel:

[The governess is thinking.] Why not break out at her on the spot and have it all over?_-give it to her straight in her lovely little lighted face? "You see, you see, you KNOW that you do and that you already quite suspect I believe it; therefore, why not frankly confess it to me, so that we may at least live with it together and learn perhaps, in the strangeness of our fate, where we are and what it means?” This solicitation dropped, alas, as it came: if I could immediately have succumbed to it I might have spared myself-well, you'll see what. Instead of succumbing I sprang again to my feet, looked at her bed, and took a helpless middle way. "Why did you pull the curtain over the place to make me think you were still there?” Flora luminously considered; after which, with her little divine smile: “Because I don’t like to frighten you!” "But if I had, by your idea, gone out-?? She absolutely declined to be puzzled; she turned her eyes to the flame of the candle as if the question were as irrelevant, or at any rate as impersonal, as Mrs. Marcet or nine-times-nine. “Oh, but you know," she quite adequately answered, "that you might come back, you dear, and that you HAVE!” And after a little, when she had got into bed. (James, 1960, pp. 46-47)

This dialogue is a telling example of the difficult "ideological becoming” process, in which the governess tries to impose her idea upon Flora and tries to elicit her desired conclusion. By "You see, you see... you KNOW that you do and that you already quite suspect I believe it;" the governess means that Flora not only sees the ghost of Miss Jessel, but is actually aware that the governess might have noted that she sees it. By “... therefore, why not frankly confess it to me...” the governess even commands a voluntary confession from Flora.

However, the governess's remarks clearly fail in its intention when it enters into Flora's speech context. Flora explains that she gets up at night only because she thinks that someone is walking in the grounds. She denies that she sees anybody, and explains that she draws the curtain to cover the fact that she is out of bed simply because she doesn't want to frighten the governess.

The whole dialogue shows that the governess's interrogation, fully charged with fire, misfired when entering into Flora's domain of speech context. The tension between this fire and misfiring is where aporia occurs. It's all too easy for a reader to be trapped in this tension and fail to figure out who is the more credible, the governess, or little Flora? This again results in indeterminacy. 


\section{Double-Voiced Active Discourse}

In this section I will use Bakhtin's theory of double-voiced discourse to locate the recurrence of aporia. Examples of active discourse in the embedded text of The Turn will be analyzed to that end.

Bakhtin defines double-voiced discourse as "discourse with an orientation towards another's discourse" (1984, p. 199), where "the author ... makes use of someone else’s discourse for his own purposes, by inserting a new semantic intention into a discourse which already has, and which retains an intention of its own ... In one discourse, two semantic intentions appear ...” (1984, p. 189)

Bakhtin's double-voiced discourse conflates the author's discourse and the protagonist's discourse into one presented textual discourse. The author's discourse is hidden within the protagonist's discourse. Thus, there are two semantic intentions within one presented textual discourse.

When Baktin applies “the author's discourse” in analysis, he didn’t distinguish between the author outside the text the author inside the text. There is no distinction between the author in real life and the author who appears to us through the text, or rather, the implied author. However, my reading would engage his concept of author with the implied author.

In "Hearing Voices in Narrative Texts" (1998), Richard Aczel (1998) expounded the relationship between the three types of discourse distinguished by Bakhtin, i.e. the "unidirectional," "vari-directional," and "active" discourses. Aczel points out that unidirectional double-voiced discourse represents "an intention on the part of the author to make use of someone else's discourse in the direction of its own particular aspirations" (Bakhtin, 1984, p. 193). In this case, the author's aspiration is in accordance with that of the applied discourse. The author is sort of stylizing "another's style in the direction of that style's own particular tasks” (Bakhtin, 1984, p. 193). In vari-directional double-voiced discourse, the speaking voice occupying another's discourse deliberately misbehaves with the intended semantic direction of that discourse. Bakhtin uses parody as an example because "in contrast to stylization parody introduces into that discourse a semantic intention that is directly opposed to the original one” (Bakhtin, 1984, p. 193). In these two types of double-voiced discourses, the discourse applied by the author in writing actually plays a passive role. They are explicitly used by the author either to advance his own voice or as a butt of irony.

In the third type of double-voiced discourse, the discourse of the other is active because "[a]nother's discourse ... is not reproduced with a new intention, but it acts upon, influences, and in one way or another determines the author's discourse, while itself remaining outside it” (Bakhtin, 1984, p. 195). Bakhtin's example for this type of discourse is "hidden polemic." The hidden polemic exists in the constructed referential object in a way that every statement about the object serves as a blow upon the other's discourse on the same theme, at the other's statement about the same object.

Following Bakhtin's definition of the double-voiced active discourse, I will take the embedded story as a focus of the double-voiced discourse analysis in The Turn. In The Turn, with the shift of narration from the frame text to the embedded text, the discourse also undergoes a shift. The embedded story of The Turn is a transcript taken down by the narrator "I" in the frame story, which is said to be a recording of the story told by Douglas from the manuscript written by the governess and entrusted to him before her death some twenty years ago. In this situation, it is seen that the speaker is trying to distance himself from the governess's discourse or even conceal himself behind the governess. The transcript seems to be a discourse dominated by the governess's voice. An examination of the speech types used by the governess in telling her story will illustrate 
how this determining effect of the governess's discourse has been achieved. The governess mainly adopts free indirect speech and direct speech to present her past experience.

Free indirect speech refers to the unquoted report of speech and thought, while direct speech refers to the quoted report of speech and thought. The governess' narration of the story is a mixture of free indirect speech and direct speech. The free indirect speech as appeared in the governess's narration of the story can directly represents her thought and her observations on other characters. In a sense, this free indirect speech can be regarded as an unframed interior monologue which represents her psychological movements and her after thoughts of the past events. This interior monologue gives the readers access to the mind of the governess as a protagonist, and produces an effect of authenticity. As Dorrit Cohn points out in her Transparent Minds (1978), that free indirect discourse actually provides a window for reading the character's mind. It is only in literary works that human minds can be accessible and knowable (p. 3). Reading the governess's recollections of the story is like reading her mind, in this sense, free indirect speech enhances the authenticity of the governess' voice.

Direct speech appears in dialogues between the governess and other co-characters. The effect of directly presenting her co-characters' speech is also a way of making the story credible. It also reinforces the sense of authenticity by showing what other co-characters have exactly said when the story happens. It's quite apparent that both free indirect speech and direct speech employed in the governess's rendition of the story are efforts to make her rendition credible. With the application of free indirect speech and direct speech, the governess's discourse becomes a determining discourse over the concealed author's discourse.

One cannot fail to notice, however, that two letters, which prove central to the story are not directly and fully presented: one is the schoolmaster's letter to the Master, which is later sent down to the governess by the Master; the other is the letter written by the governess to the Master, which is unfortunately stolen and burned by little Miles. With the interplay of free indirect speech and direct speech revolving around the two letters, the content of the two letters is skillfully covered, while discussions over the two letters are clearly presented. The governess's application of free indirect speech and direct speech in presenting her experience aims to add credibility to her narration. However, the suppressed information concerning the actual content of these two letters, which is disguised by the interplay of these speeches, creates a "hidden polemic" in the governess's discourse since the two letters are the key to understanding the story. The suppression of the content of the two letters casts doubts on the reliability of the governess as a narrator. Readers may well be left wondering: Why does not the governess present the two letters directly in full text? Is the governess a truly reliable voice in the discourse? This hidden polemic thus deals a severe blow to the governess's assumed authenticity in telling the story. The following part is a close look at how these two crucial letters are presented.

The arrival of the first letter is described in free indirect speech as "composed of a few words enclosing another, addressing to himself (the Master), with a seal still unbroken” (James, 1960, p. 13). However, the master's remarks are fully presented as it is in quotation marks: "This, I recognize, is from the headmaster, and the headmaster's an awful bore. Read him, please; deal with him; but mind you don't report. Not a word. I'm off!” (James, 1960, p. 13) It is quite obvious that the story evolves from the point of Miles' dismissal from school and the headmaster's letter is the only clue that may explain Miles' dismissal. Readers naturally wonder what the schoolmaster has written in his letter. This curiosity, however, is baffled by the interplay between free indirect speech and direct speech in representing the two letters. When the governess intends to confide to Mrs. Grose and even offers the latter to read the schoolmaster's letter, it turns out that Mrs. Grose cannot read. As a 
result, the readers' access to the content of the schoolmaster's letter depends entirely on the interpretation of the governess. The dialogues between the two are presented in direct speech. But the original letter of the schoolmaster's is not presented in full quotation as that of the Master's. The following shows how elusive direct speech can be:

At this she (Mrs. Grose) raised her eyes, which she had turned from me; I (the governess) saw them fill with good tears. "What has he done?” I hesitated; then I judged best simply to hand her my letter — which, however, had the effect of making her, without taking it, simply put her hands behind her. She shook her head sadly. "Such things are not for me, miss.” My counselor couldn't read! I winced at my mistake, which I attenuated as I could, and opened my letter again to repeat it to her; then, faltering in the act and folding it up once more, I put it back in my pocket. "Is he really BAD?” The tears were still in her eyes. "Do the gentlemen say so?” "They go into no particulars. They simply express their regret that it should be impossible to keep him. That can have only one meaning.” Mrs. Grose listened with dumb emotion; she forbore to ask me what this meaning might be; so that, presently, to put the thing with some coherence and with the mere aid of her presence to my own mind, I went on: “That he’s an injury to the others.” (James, 1960, pp. 13-14)

Mrs. Grose understands from the governess remarks that the reason for Miles's dismissal is his being "an injury to his mates" (James, 1960, p. 13). What kind of injury could he have been? According to the governess the reason for Miles's dismissal is not clearly mentioned. Then, where does this "injury to his mates" come from? The governess seems to be self-contradictory, which makes the reason for Miles's dismissal indeterminate. And this suppressed information pertaining to the content of the schoolmaster's letter could well serve as an attack upon the governess's discourse, in which the interplay of free indirect speech and direct speech pretend to establish her authenticity in telling the story. In other words, this suppressed information is where the hidden polemic lies. This hidden polemic undermines the authenticity of the governess' discourse, which in turn produces ambiguity in reading the story.

In the following part, I will examine how the second letter is presented within the governess's discourse. This letter is written by the governess and intended to invite the Master to conduct an interview in Bly, but an interview of what has never been mentioned. However, it does not reach the Master since it is stolen and later burnt by Miles. In the following dialogue, the governess and little Miles are discussing the missing letter:

[The governess:] “And you found nothing!” I [the governess] let my elation out. He [Miles] gave the most mournful, thoughtful little headshake. "Nothing.” "Nothing, nothing!” I almost shouted in my joy. "Nothing, nothing," he sadly repeated. I kissed his forehead; it was drenched. "So what have you done with it?” "I’ve burned it.” (James, 1960, pp. 91-92)

Readers are left wondering: if the letter says nothing, then what is the necessity of Miles's burning of it? This letter is again a "hidden polemic" in the governess's discourse, which underscores the authenticity of her voice. This hidden polemic serves to arouse doubts in the readers' minds and in turn generates aporia in the reading of the story.

\section{Conclusion}

To sum up, Bakhtin's philosophy of language provides grounds for a discursive approach to locate the aporia in the reading of The Turn. His notion of the "conceptual horizon" helps us to see that a voice is open to multiple interpretations by people because of their distinctive "conceptual horizons". "Conceptual horizon” in fact brings about opaque communication in dialogues. Differences in conceptual horizons sometimes serve to block communication and consequently increase the chances of misunderstanding. 
Bakhtin's theory of double-voiced discourse contends that there are two semantic intentions within one discourse. The governess's discourse that claims authenticity in telling the ghost story from her memory is greatly shaken by the "hidden polemic": the constructed referential object by James—-the two letters. The effect of this double-voiced discourse eventually makes the governess a dubious narrator and creates aporia in reading. Although Bakhtin did not mark the difference between the author outside the text and the implied author, my critical engagement regarding the concept of author would prefer the implied author to the author outside the text. Although Bakhtin's dialogic theory of conceptual horizon and double-voiced discourse does not engage the readers in the cycle of communication, I hope my attempts to locate the indeterminacy in James's text, not only enriches the reading of the text itself, but also completes Bakhtin's vision.

\section{References}

Aczel, R. (1998). Hearing voices in narrative texts. New Literary History, 29(3).

Bakhtin, M. (1981). Discourse in the novel. In M. Holquist (Ed.), The dialogic imagination. Austin: University of Texas Press.

Bakhtin, M. (1984). Problems of Dostoevsky's poetics. C. Emerson (Ed. \& Trans.). Minneapolis: University of Minnesota Press. Bal, M. (1997). Narratology, introduction to the theory of narrative. Toronto: University of Toronto Press Incorporated.

Booth,W. C. (1975). A rhetoric of irony. Chicago: The University of Chicago Press.

Cohn, D. (1978). Transparent minds: Narrative modes for presenting consciousness in fiction. Princeton, N.J.: Princeton University Press.

Cranfill, T. M., \& Clark, Jr. R. L. (1965). An anatomy of The Turn of the Screw. Austin: University of Texas Press.

Eco, U. (1990). The limits of interpretation. Bloomington [etc]: Indiana University Press.

Honecutt, L. (1994, November 10). Chapter 2 - Bakhtin and his world (Continued). Retrieved June 20, 2006 from http://www.public.iastate.edu/ honeyl/bakhtin/chap2b.html

James, H. (1960). The Turn of the Screw. In G. Willen (Ed.), A case book on Henry James's “The Turn of the Screw”. New York: Thomas Y. Crowell Company.

James, H. (1985). What Maisie Knew. (P. Theroux, Introdu.). London: Penguin Group,

Klages, M. (2001, November 13). “Mikhail Bakhtin”. Bakhtin Lec. Retrieved June 20, 2006 from http://www.colorado.edu/English/courses/ENGL2012Klages/bakhtin.html

Norrman, R. (1982). The insecure world of Henry James's fiction: Intensity and ambiguity. London: The Macmillan Press.

Samuels, C. T. (1971). The ambiguity of Henry James. Chicago: University of Illinois Press.

The Free Encyclopedia. (December 11, 2006). Implied author. Retrieved from http://en.wikipedia.org/wiki/Implied_author Wilson, E. (1960). The ambiguity of Henry James. In G. Willen (Ed.), A case book on Henry James's "The Turn of the Screw". New York: Thomas Y. Crowell Company.

Zima, P. V. (1999). The philosophy of modern literary theory. London: The Athlone Press. 